\title{
骨肉腫担癌マウスに対するレーザーサーミア
}

$\begin{array}{lrl}\text { 脇田 郷, 松井 } & \text { 宣夫, 太田 弘敏, } \\ \text { 大塚 } & \text { 隆信, 服部 } & \text { 正広, 山田 邦雄 }\end{array}$

名古屋市立大学医学部整形外科

\section{Experimental Study of Laserthermia on Osteosarcoma Bearing Mice}

Satoshi Wakita, Nobuo Matsui, Hirotoshi Ohta, Takanobu Ohtsuka, Masahiro Hattori and Kunio Yamada

Department of Orthopedic Surgery, Nagoya City Univ. Medical School

\section{ABSTRACT}

We have investigated the effects of local hyperthemia using Na:YAG laser and shortwave radiofrequency. Groups of $\mathrm{C} 3 \mathrm{H} / \mathrm{He}$ mice transplanted tumors (Dunn osteosarcoma) were treated with local hyperthermia. Heating was performed for 15 minutes in laserthermia and 60 minutes in radiofrequency. After the treatment with each heating systems at $42.5 \sim 43^{\circ} \mathrm{C}$, animals were subsequently sacrificed at 3 and 7 days. We observed the pathohistological and electron microscopical changes in the tumor cells and tissue. In spite of using different heating systems and treating different heating time, almost same tumor destructive changes were observed. These results suggest that hyperthermia is one of the effective treatment methods for osteosarcoma and in addition to heat, Nd:YAG laser energy may have another efEect.

\section{はじめに}

近年, 覀性腫㘼に対する局所温熹潦法は手術療 法, 化学療法, 放射線療法などとの併用療法とし て用いられ，その有用性が誈価されている。しか し骨肉腫など整形外科領域における温熱潦法に関 する報告例は少なく，治療効果，作用機序など不 明な点が数多く残されている。今回我々は,レー ザー加温とRF誘電加温による局所温熱療法が骨 肉腫細胞に及ほす影留と加温方法による相違につ いて，奏験的に検討した。

\section{実験材料・方法}

使用した動物は 3 週令C $3 \mathrm{H}$ マウスで, との背部 皮下にDunn学肉朠を移植し, 腫焙径が約 $1.5 \mathrm{~cm}$ になったととろでペントバルビタール(ネンブタ 一ル，大日本製薬）で腹腔内麻酔を行い局所温熱 瘵法を行った。加温はSLTコンタタトレーザー CL50 (SLT ジャパン社紗) と, 実験用RF誘電加温

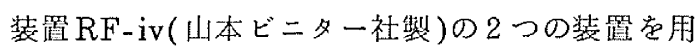
いて行った。レーザー加温はセラミック製穿刺型

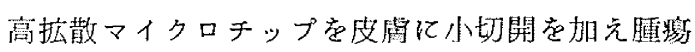

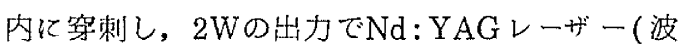
長 $1.06 \mu \mathrm{m})$ 在照射し, 誘電加温 $(8 \mathrm{MHz})$ は直径 20 $\mathrm{mm}$ (隄極)と $30 \mathrm{~mm}$ (陰極) の電極間に腫垓をは み $4 \mathrm{~W} \sim 7 \mathrm{~W}$ 出力で行っだ。温度測定は腫煌内に温 度センサーを刺入して行い, 抗腫第効果が認めら れている $42.5^{\circ} \mathrm{C} \sim 43^{\circ} \mathrm{C}$ 維持し, 加温時間はレー ザー加温15分, 誘電加温60分とした。

それぞれの加温方法につき病理組織標本，電顕 標本を加温後 3 日および 1 週で採取し比較検討し た。電䫓標本については，温熱燎法により生した 堎死組織に隣接する腫啰組織より採取した。 


\section{結果}

誘電加温磷の病理組絨慓本では，加温電極淔下

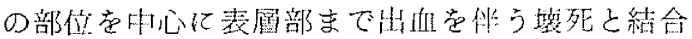
織の增生，浮腫がみられたが，腄熄底部の燃部筋 層に壊死はみられず辺緣部には腫璌細胞が残存し ていた(Fig.1)。加温後1㥜觉経過すると残存した 辺緣部蕾㹲緗胞の增殖がみられ，向管の新生，結 合織の増生も観察された(Fig.2)。留顕栖本では

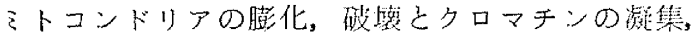
核の粗造化，紐胞間隙の拡大などの紐胞機能の低 下を示生所見がみられ，乙礼らの変化は加潰後 1 週を経過しても観祭された(Fig.3)。

レーザー加温群では刺入したレーザープローブ を中心とした腄菂組織の出血を伴う壊死が钼祭さ れ(Fig.4)，加温後 1 週を経過すると，残存した 辺緣部腫堵細胞の增殖がみられ壞死領域内には結 合織の增生もみられた(Fig. 5)。電䫓櫒本ではる

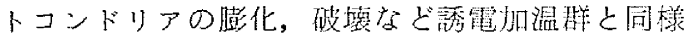
の変化がみられた(Fig.6)。

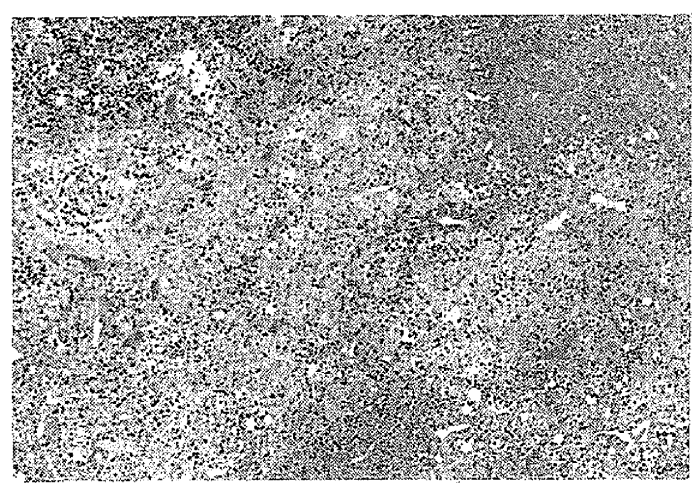

Fig. 1 RF誘電;加温 ( 3 日後)

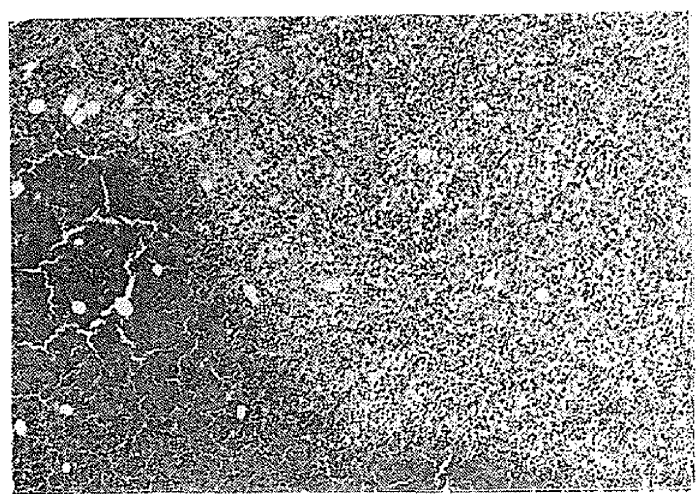

Fig. 2 RF 誘電加温 ( 1 鼍後)

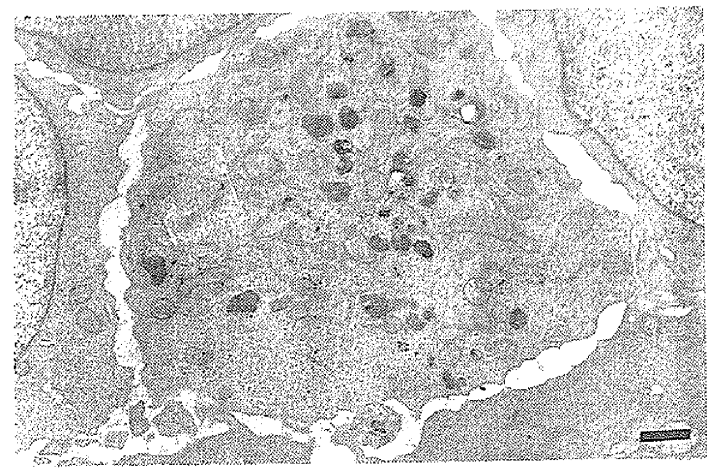

Fig. $3 \mathrm{RF}$ 榙電加温 (電顕像)

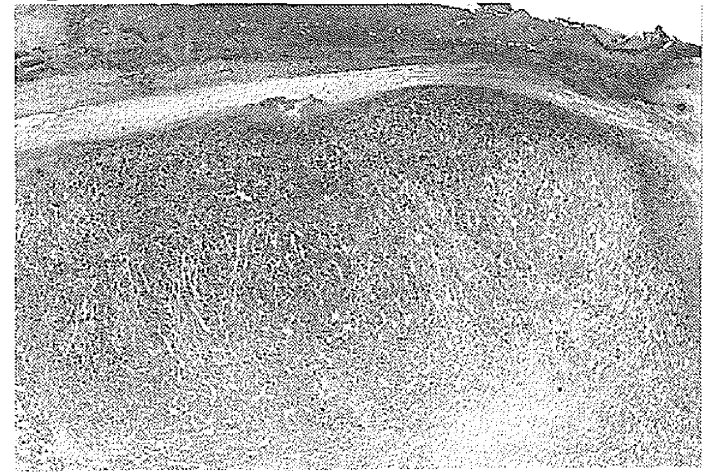

Fig. 4 レーザーJ゙温（ 3 日後)

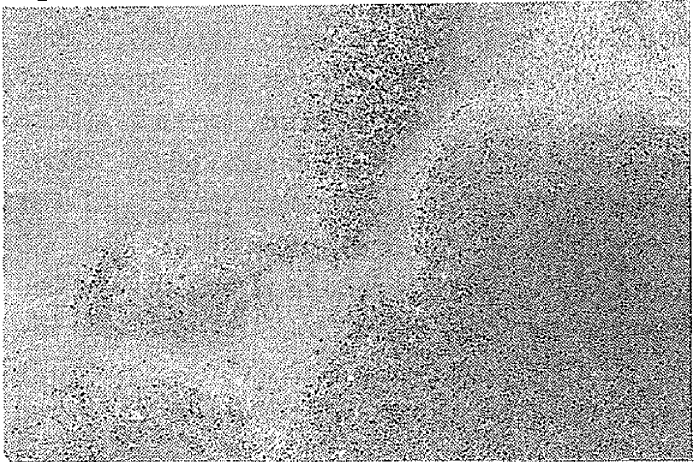

Fig. 5 レーザー加温 ( 1 週後)

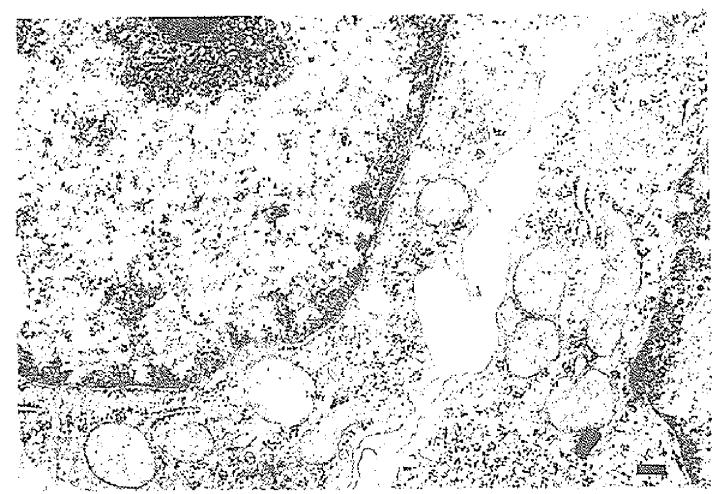

Fig. 6 レーザー加温 (電影像) 
以上の結果より，温熱憏法算独では，いずれの

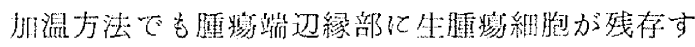

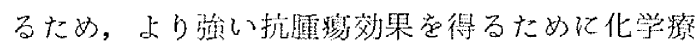
法を併用した温照化学療法を追加していった。化 学療法削は 2 檑類のりン脂質を用いた熱感受性り ポソーム内にシスプラチンを包埋したTAC-1043

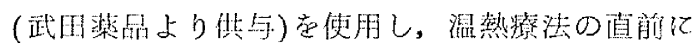
$5 \mu \mathrm{g} / \mathrm{g}$ 尾静眽より静眽内に投与した。TAC-1043 は $38^{\circ} \mathrm{C}$ 以下゙のシスプラチン放出滦は10\%以下で あるが，41ํ以上では眼時にリポソームが融解し 包埋されたシンプラチンの70\%以上放出する特

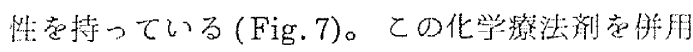
した絬果，RF加温群，レーザー加温群の雨群に 温熱燎法に上る填死領域が拉大する傾问がみられ,

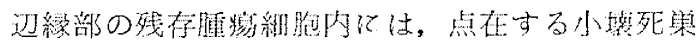
がみられた。この辽緣部てみられた小塤死領域は， 化学㾘法の效果と考えられた(Fig.8)。

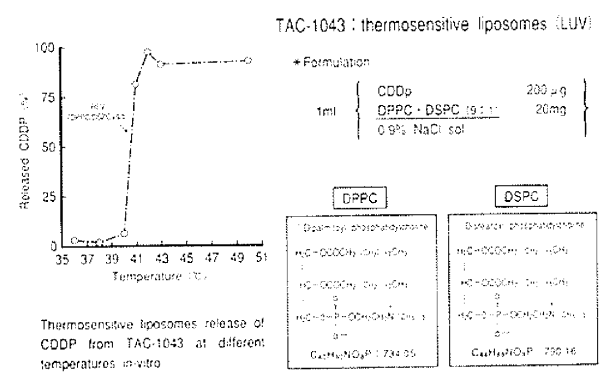

Fig. 7 TAC - 1043

慧感受性りポソーム包姐シスプラチン

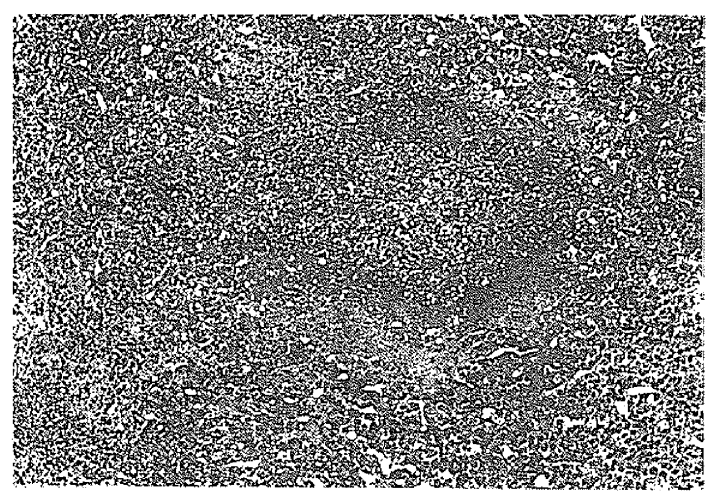

Fig. 8 温熱化学潦法 ( 3 日後)

\section{考 察}

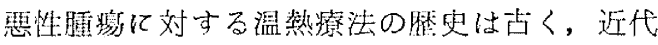
的なものは1866年Busch ${ }^{1)}$ の䞆面に生じた肉朠が 丹唡による登熱により消失したという記这に始ま

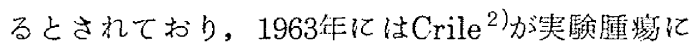
対するWater Bath 届用いた温熱效果について報 告している。てれ以後, 加温技術の進歩により, さまざまなエネルギーが温熱療法に利用されてい る。しかしえれらの作用機序や骨闪腫に対する効 果などについては不明な点が数多く残されている。 今回我々の用いたR R 誘電加温では深達性や加 温範囲が大きく, 非侵毁的加温という点ではレー ザー加温に隻ると思われるが, 一方, Nd-YAGレ 一ザー加温ではポータブル機器で行えるため専用 室は不要であり，短時閏の処置で效果が得られ璖 部の小睡埸も治療可能である利点を持っている。

徤来, 温熱際法に上る抗腫埸効果は $43^{\circ} \mathrm{C}$ 前後の

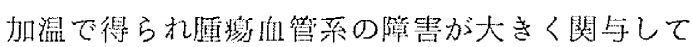
いると報告され, Emami ら ${ }^{3)}$ は, ラットの横紋筋 肉臛に刘するRF 波を用いた局所温熱燎法におい

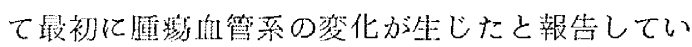
る。今回，我々の奏験においても腫影内出血などの

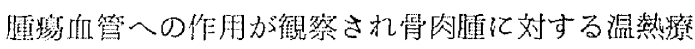
法の有用性が示唆された。レーザーサーミア譬では， RF 加温群に比べ短時䦬の加温処埴で同等の抗腫

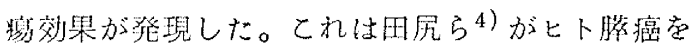
用いた奏駰で指摘したNd-YAGレーザーエネルギ 一自体の持つ殺細胞效果の関与を示唆している。 鼬熱による腄猪細胞の微細構造に対する影愁に

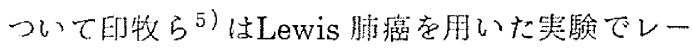
ザーサーミアの最初の標的器宫がミトコンドリア

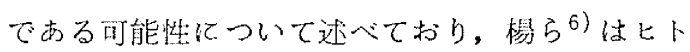
胃癌細胞格飞対する恒温水による加温実験の初期

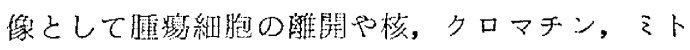
コンドリアなどの変化について述べている。骨肉 睡細胞では河加鼬群にミトコンドリアの膨化，破 壤などてれらの報告例と類似した変化が観察され， レーザーエネルギーによる標的器官の確認は困䧼 であった。しかし前述の如くレーザー加温では RF 加温に比し短時間の処置であるにもかかわら ず，雨者には闹様な抗胛额幽の変化が锥祭されて 
おり, 加温処置による抗腫焬效果の発現に先行し てレーザーエネルギーによる障害が発現するとも 推測された。峦た，今回温熱化学療法に用いた化 学療法㓮TAC-1043は, 加温部でシスプラチンが放 出されるため, より有効なシスプラチンと腫煌細 胞との接触が可能となり RF加温やレーザー加温な どの局所温熱療法の併用療法薬剤として有用な薬 凨であるとおもわれた。

\section{結 語}

1) RF 霄電加温とNd-YAGレーザー加温の営肉腫 に及ほす組織学的影響につきマウス移植腫燸

(Dunn osteosarcoma) 妾用い実験的に検討した。 2)加温処置により骨肉腫組織には血管損傷などの 変化がみられ, 電顕的にも微細構造に紐胞障害 性の変化が観察された。とれらにより骨肉腫に 対する温熱療法の有用性が示唆された。

3)レーザーサーミア群ではより短時間の加温処置 で抗腫第効果の発現がみられ，骨肉腫に対する Nd-YAGレーザー自体が持つ殺細胞効果の存在 が示唆された。

4)熱感受性りポソーム包埋シスプラチンTAC-1043 は局所温熱療法の併用薬剂として有用であると 考えられた。

\section{文献}

1) Busch, W.: Uber den einfluss welchen heftigere Erypipelen Zuweilen auf organisierte Neibildungen ausuben. Verhandel Nature Press Rhein Westphal, 23: 28-35, 1866.

2)Crile, G., Jr.: The effects of heat and radi ation on cancers implanted on the feet of mice. Cancer Res., 23: 372-380, 1963.

3) Emami B., Nussbaum G.H., TenHaken R.K., Hughes W.L.: Physiolosical effects of hyperthermia: Response of capillary blood and structure to local tumor heating. Radiology, 137: 805-809, 1980.

4)田尻久雄, 斉藤大三, 㙁谷英史, 他: 光化学療 法および局所温熱潦法の検討一実験的研究を含 めて-. Gastroenterol. Endosc., 28:2282-2289.
1986.

5)印牧直人, 恒川洋, 伊藤圓: Nd:YAGレーザー を用いたレーザー温熱療法(レーザーサーミア ) に関する病理組織学的研究. 日本レーザー医学 会誌, 10:11-18, 1990.

6)楊虎川, 胡慶和, 鄂征: ハイパーサーミア(40〜 $\left.\sim 44^{\circ} \mathrm{C}\right)$ にるとト胃癌細胞株KATO-而の生物 学的反応と微細構造の変化について. 東京医学, 92 : 114-122, 1985. 